\title{
Honoré de Balzac, Un Debutto nella vita
}

\section{Marco Stupazzoni}

\section{(2) OpenEdition}

\section{Journals}

\section{Edizione digitale}

URL: http://journals.openedition.org/studifrancesi/2199

DOI: 10.4000/studifrancesi.2199

ISSN: 2421-5856

\section{Editore}

Rosenberg \& Sellier

\section{Edizione cartacea}

Data di pubblicazione: 1 aprile 2014

Paginazione: 161

ISSN: 0039-2944

\section{Notizia bibliografica digitale}

Marco Stupazzoni, « Honoré de Balzac, Un Debutto nella vita », Studi Francesi [Online], 172 (LVIII | I) |

2014, online dal 01 avril 2014, consultato il 18 septembre 2020. URL : http://journals.openedition.org/ studifrancesi/2199; DOI : https://doi.org/10.4000/studifrancesi.2199

\section{Questo documento è stato generato automaticamente il 18 settembre 2020.}

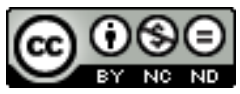

Studi Francesi è distribuita con Licenza Creative Commons Attribuzione - Non commerciale - Non opere derivate 4.0 Internazionale. 


\title{
Honoré de Balzac, Un Debutto nella vita
}

\author{
Marco Stupazzoni
}

\section{NOTIZIA}

HONORÉ DE BALZAC, Un Debutto nella vita, a cura di Mauricio DUPUIS, Roma, Robin edizioni, «La Biblioteca», 2012, pp. 255.

1 Pubblicata, a puntate, ne «La Législature», tra il 26 luglio e il 4 settembre 1842 col titolo di Le Danger des mystifications, questa «scène de la vie privée» balzachiana è dedicata, non a caso, a Laure de Surville, sorella di Balzac, la quale consegnò, anni prima, il manoscritto di un racconto intitolato: Le Voyage en coucou (successivamente inserito, nel 1854, nella raccolta: Le Compagnon du foyer) che, per dichiarazione dell'autrice stessa, avrebbe direttamente ispirato il testo balzachiano.

2 L'opera di Laure de Surville è presentata, in traduzione, nell'appendice di questa nuova edizione italiana a di Un Début dans la vie (Il Viaggio in cuculo, pp. 210-238), curata, anche per quel che riguarda l'apparato delle note al testo, da Mauricio Dupuis.

3 Nella sua Postfazione all'opera balzachiana, il curatore si sofferma nell'analisi della struttura - originariamente suddivisa in 14 capitoli - e delle dinamiche interne del racconto con particolare riferimento alla circolarità del sistema dei personaggi (cfr. pp. 204-209). Nelle pagine seguenti, sono presenti una Cronologia delle opere di Balzac (pp. 239-2479 ed un elenco - organizzato secondo la suddivisione in macro ed in microstrutture della Comédie humaine - delle principali (e più recenti) traduzioni dei romanzi e dei racconti di Balzac pubblicati nel nostro Paese. 